UDK 366.542:[004:3379

https://doi.org/10.18485/union_pf_ccr.2021.ch22

Esther Angonemi Ebimoghan*

\title{
FINANCIAL INCLUSION THROUGH INNOVATIONS - IMPROVING CONSUMER PROTECTION IN DIGITAL FINANCIAL SERVICES
}

\begin{abstract}
The central goal of this paper is to investigate how to promote financial inclusion by addressing the gaps of consumer protection in Digital Financial Services (DFS). This paper provides policy recommendations that address the asymmetry between payment service providers and consumers. To achieve this, a comparative research methodology with a functional approach from a micro-level was used to compare the institutions and gaps in different socio-economic settings. As this approach provides learning to examine the differences and similarities in legal regimes and address practical issues in policy reforms and development through primary and secondary sources. The result and conclusion of this research show that an efficient consumer protection framework is rudimentary to build consumer trust and confidence in Digital Financial Services which will result in an increased level of integration into formal financial systems.
\end{abstract}

Key words: Financial inclusion, M-pesa, Sub-Sharan Africa, European Union, Payment Services Directive, consumer protection, digital financial services, mobile money, Fintech.

\section{INTRODUCTION}

\subsection{THE IMPORTANCE OF FINANCIAL INCLUSION}

Financial exclusion is still a challenge which impedes the underprivileged from access to financial services. ${ }^{1}$ Through financial inclusion, disadvantaged and low-income groups can access financial products and services to improve their living standards. ${ }^{2}$ Inaccessibility of financial services can result in social marginality and poverty. ${ }^{3}$ In order to manage daily financial transactions, credit

* Student in the LL.M in International Business Law program, Legal Studies Department of Central European University, Vienna, Austria

e-mail: Ebimoghan_Esther@student.ceu.edu

1 Leeladhar, V., 2005, Taking banking services to the common man - financial inclusion, Mumbai, Reserve Bank of India Bulletin, (https://www.bis.org/review/r051214e.pdf, 3. 11. 2020).

2 Mitton, L., 2008, Financial Inclusion in the UK: Review of policy and practice, (https://www.jrf. org.uk/report/financial-inclusion-uk-review-policy-and-practice, 27. 10. 2020).

$3 \quad$ Ibid. 
flows, expenditures and profits, financial inclusion is crucial. ${ }^{4}$ In 2016, over 37 million European Union adult citizens lacked access to formal financial services. The rate of financial exclusion in the EU is depicted as follows Romania (39.2\%), Bulgaria (37\%), Slovakia (22.8\%), Hungary (27.7\%) and Poland $(22.1 \%) .^{5}$ In contrast, Denmark and Finland have a 100\% rate of financial inclusion of which Sweden, Germany and Netherlands have $99 \%$ of their population integrated in formal financial systems. ${ }^{6}$

The Revised Payment Services Directive (PSD 2) is a European Union Directive that regulates digital payments with the aim of promoting competition within banking and non-banking financial institutions to harmonize consumer protection and the duties of payment services providers within Europe. ${ }^{7}$ Innovations through Digital Financial Services (hereinafter DFS) have been critical to achieve financial inclusion. ${ }^{8}$ Through mobile phones and mobile wallets financial services can be accessed. ${ }^{9}$ However, a lack of efficient regulatory framework to guarantee consumer trust and confidence in DFS will perpetuate financial exclusion. ${ }^{10}$

The promotion of financial inclusion is chiefly in line with my work as a Consultant for the African Foundation for Development (AFFORD, UK) an International Organization with a mission "to expand and enhance the contributions Africans in the diaspora make to African development through promoting the investment potential of diaspora in the SME sector". ${ }^{11}$

AFFORD helps to promote financial inclusion through its accelerator programme that provides access to credit for SME-s in emerging markets. ${ }^{12}$ It thus, helps to facilitate the transition of SME-s in the informal sector to the formal financial sector to promote access to finance.

More so, the World Bank Group accesses financial inclusion as a catalyst for poverty reduction. ${ }^{13}$ With close to 1.7 billion adults still unbanked, the world bank group plays a critical role in advancing access to finance through its financial sector expertise. ${ }^{14}$ The World Bank aids the process of financial inclusion

$4 \quad$ Ibid.

5 WSBI, 2016, Close to 40 million EU citizens outside banking mainstream, (https://www.wsbiesbg.org/press/latest-news/Pages/Close-to-40-million-EU-citizens-outside-banking-mainstream.aspx, 29. 10. 2020).

$6 \quad$ Ibid.

7 Payment services (PSD 2) - Directive (EU) 2015/2366, (https://ec.europa.eu/info/law/ payment-services-psd-2-directive-eu-2015-2366_en, 5. 11. 2020).

8 Gibson, E., Lupo-Pasini, F., Buckley, R. P., 2015, Regulating Digital Financial Services Agents in Developing Countries to Promote Financial Inclusion, Singapore Journal of Legal Studies, Vol. 1, No. 1, pp. 26-45, 27.

9 Loubere, N., 2017, China's Internet Finance Boom and Tyrannies of Inclusion, China Perspectives, Vol. 4, No. 112, pp. 9-18, 9.

10 Gibson, E., Lupo-Pasini, F., Buckley, R. P., 2015, p. 37.

11 https://www.afford-uk.org/, 5. 11. 2020; https://www.afford-uk.org/current-funded-programmes/, 7. 11. 2020.

12 https://www.afford-uk.org/abc-benin-accelerator-programme/, 6. 11. 2020.

13 The World Bank, 2018, Financial Inclusion: Financial inclusion is a key enabler to reducing poverty and boosting prosperity, (https://www.worldbank.org/en/topic/financialinclusion/ overview, 9. 11. 2020).

14 Ibid. 
by promoting innovations in payment methods from cash to digital payments and support through efficient legal framework for access to finance for SME-s. ${ }^{15}$ Programs such as the Women Entrepreneurs Finance Initiative (We-Fi) address the financial challenges of SME-s owned by women. ${ }^{16}$ Digital Economy for Africa (DE4A) is an initiative that provides support to build a sustainable digital ecosystem in Africa. ${ }^{17}$ Again, the World Bank is committed to improving the reach of financial services to 1 billion adults in 25 countries with the highest rate of financial exclusion. ${ }^{18}$ The World Bank Group is also instrumental in providing reforms in payment systems to facilitate innovations in payment services through electronic payment methods. ${ }^{19}$ This includes the provision of a sound and efficient regulatory framework to address issues of consumer protection and transparency in payment systems. ${ }^{20}$

Digital solutions are critical for financial inclusion in Africa. ${ }^{21}$ Through this medium, financial inclusion rates have increased from $24 \%$ in 2011 to $34 \%$ in $2014 .{ }^{22}$ However, over 350 million adults in Sub-Saharan Africa are financially excluded. ${ }^{23}$ Global Findex data show that more women and youths in rural areas are financially excluded due to the absence of bank branches in low-population density areas. ${ }^{24}$ This gap is increasingly filled by DFS providers who utilize electronic payment methods to improve financial inclusion in rural areas. As a result, over $40 \%$ of the adult population in Kenya, Tanzania, Zimbabwe, Ghana, Uganda, Gabon and Namibia have access to financial services through digital platforms. ${ }^{25}$

AFFORD is addressing the issue of access to finance in Sub-Saharan Afri$\mathrm{ca}$ and transitioning entrepreneurs from the informal to formal financial sector to drive financial inclusion. ${ }^{26}$ The World Bank Group is providing credit infrastructure services through secured transactions reforms and collateral registry reforms to address the impediments of access to credit and the gaps in financial

15 The World Bank, 2018.

16 The World Bank, 2018, Financial Inclusion: Financial inclusion is a key enabler to reducing poverty and boosting prosperity, (https://www.worldbank.org/en/topic/financialinclusion/ overview\#2, 9. 11. 2020).

17 Ibid.

18 The World Bank, 2018, Financial Inclusion: Financial inclusion is a key enabler to reducing poverty and boosting prosperity, (https://www.worldbank.org/en/topic/financialinclusion/ overview\#2, 9. 11. 2020) through the universal financial access initiative 2020.

19 Ibid.

20 Ibid.

21 Stijns, J-P., 2017, Digital Financial Inclusion in sub-Saharan Africa (European Investment Bank) Round Table Proceedings, (https://www.eib.org/attachments/general/events/africa_ day_2017_roundtable_proceedings.pdf?cid=sn_twitter_Report-book_2017-10-18-01_en_ na_Region-Africa_InternationalDevelopment-outsideEU 6. 11.2020), p. 1.

22 Ibid., p. 2.

23 Demirguc-Kunt, A., Klapper, L., Singer, D., Oudheusden, P. van, 2015, The Global Findex Database 2014: Measuring financial inclusion around the world. Policy research working paper 7255, World Bank, (https://www.worldbank.org/content/dam/Worldbank/Research/GlobalFindex/PDF/N2Unbanked.pdf, 31. 10. 2020).

24 Stijns, J-P., 2017, p. 2.

25 Ibid., p. 3.

26 https://www.afford-uk.org/, 5. 11. 2020. 
inclusion. ${ }^{27}$ These solutions are at the forefront of driving financial inclusion for vulnerable and disadvantaged groups in rural areas.

\subsection{ROADMAP}

This paper focuses on the hypothesis that a lack of efficient consumer protection policies in DFS will perpetuate financial exclusion. Its central question is how to promote financial inclusion by addressing the gaps of consumer protection in DFS. This paper provides recommendations that address the asymmetry between payment service providers and consumers. To achieve this, it first discusses financial inclusion and its objectives. It will then examine DFS with reference to fintech innovations in Kenya and China. It also shows the innovations in Payment Services Directive (PSD2) and the alternatives to banking services. In a related development, it investigates the causes of financial exclusion, the issues in consumer protection and the state policy measures to address consumer protection issues.

To address the above stated issues, this paper utilizes a comparative research methodology with a functional approach on a micro-level to compare the institutions and problems in different socio-economic settings. ${ }^{28}$ This approach provides learning to compare legal regimes and address practical issues in policy reforms and development. This is achieved through evaluation and analysis of primary and secondary sources. The result and conclusion of this research show that an efficient consumer protection framework is rudimentary to build consumer trust and confidence in DFS which will result in an increased level of integration into formal financial systems. More so, financial inclusion can secure access to affordable financial products and services to all households. Again, through alternatives to banking services, provided by non-bank financial institutions through technology driven channels more groups can be integrated into financial systems. Furthermore, with the innovations in payment systems through Digital Financial Services unbanked groups have gained access to financial services. Through the right policy and regulatory framework, consumer awareness, recourse mechanism and efficient enforcement financial inclusion, consumer protection can be ensured to drive financial inclusion for vulnerable groups.

\section{FINANCIAL INCLUSION AND ITS OBJECTIVES}

Over $65 \%$ of adults in developing economies lack access to elementary financial products and services that will reduce risk, foster ease in transactions and drive access to credit services. ${ }^{29}$ According to former UN Secretary General, Kofi Annan " $\mathrm{t}$ ]he stark reality is that most poor people in the world still lack access to sustainable financial services, whether it is savings, credit or insurance.

27 World Bank Group, Credit Infrastructure, (https://www.worldbank.org/en/topic/creditinfrastructure, 5. 11. 2020).

28 Shah-Davis, S., Research Methods - Comparative Methodology, (https://uweascllmsupport. wordpress.com/2017/11/15/research-methods-comparative-methodology/, 31. 10. 2020).

29 Pazarbasioglu, C. et al., 2020, Digital Financial Services, World Bank Group, (http://pubdocs. worldbank.org/en/230281588169110691/Digital-Financial-Services.pdf, 3. 11. 2020). 
The great challenge before us is to address the constraints that exclude people from full participation in the financial sector." 30

Financial inclusion is the attainment of effective access to financial products and services from credit, savings, insurance and remittance for vulnerable and low-income groups. ${ }^{31}$ Such services should be affordable for consumers and sustainable for the service providers with the outcome of integrating low-income earners into formal financial system. ${ }^{32}$ A lack of access and unaffordability of financial services can result in financial exclusion for vulnerable groups and render them unbanked..$^{33}$ Such groups are classified as unbankable and are excluded due to high risk of lending. ${ }^{34}$ This raises questions on why many bankable groups are otherwise unbanked. A group might be unbanked due to discrimination on social, religious or ethnic prejudice. ${ }^{35}$ Again, information asymmetry can foster financial exclusion of low-income groups. ${ }^{36}$ More so, the high cost of financial services may impede households and enterprises from access as lower costs may be economically unsustainable for financial institutions. ${ }^{37}$ Through affordable finance, the poor can participate in economic activities and bridge the income inequality gaps. ${ }^{38}$ According to the World Bank Global Financial Development Report, "financial inclusion represents a core topic, given its implications for reducing poverty and boosting shared prosperity." ${ }^{39}$ Studies depict finance as a pivotal tool for poverty reduction as countries with higher rates of financial integration and development record quicker reduction in poverty. ${ }^{40}$ Financial inclusion enables empowerment, economic advancement, social inclusion and poverty reduction. ${ }^{41}$ Thus, improved access to finance can bolster poverty alleviation.

30 Cnaan, R. A., Moodithaya, M. S., Handy, F., 2012, Financial inclusion: Lessons from rural South India, Journal of Social Policy, 41(1), pp. 183-205, doi: http://dx.doi.org/10.1017/ S0047279411000377, http://repository.upenn.edu/spp_papers/164, p. 184; Annan, K., 2003, General assembly greenlights programme for the international year of microcredit 2005, United Nations press release, (http://www.uncdf.org/english/microfinance/pubs/newsletter/pages/ dec_2003/spotlight.php, 9. 11.2020).

31 Jong-Hee, K., 2016, A Study on the Effect of Financial Inclusion on the Relationship Between Income Inequality and Economic Growth, Emerging Markets Finance and Trade, Vol. 2, No. 52, p. 498.

32 Ibid., p. 498.

33 Ibid.

34 Ibid., p. 499.

35 Ibid.

36 Ibid.

37 Ibid.; World Bank Group, 2008, Finance for all? Policies and pitfalls in expanding access. Policy Research Report, 2007033387, Washington, (https://openknowledge.worldbank.org/bitstream/handle/10986/6905/417920PAPER0Fi18082137291301PUBLIC1.pdf?sequence=1\&isAllowed=y, 28. 10. 2020).

38 Cnaan, R. A., Moodithaya, M. S., Handy, F., 2012, p. 184.

39 World Bank, 2014, Financial Inclusion, Global Financial Development Report (2014), (https://openknowledge.worldbank.org/bitstream/handle/10986/16238/9780821399859. pdf? sequence $=4 \&$ isAllowed $=y, 8.11 .2020$ ).

40 Jong-Hee, K., 2016, p. 499.

41 Solo, T. M., 2008, Financial exclusion in Latin America - or the social costs of not banking the urban poor, Environment and Urbanization, Vol. 20, No. 1, pp. 47-66. 
The concept of financial inclusion is multifaceted and entails traditional banking services and DFS. ${ }^{42}$ Generally, financial inclusion entails indiscriminate access to financial products for all at a transparent and affordable cost. ${ }^{43}$ According to Fuller and Mellor, alternative welfare-directed rather than dividend-oriented financial services depict financial inclusion. ${ }^{44}$ Other scholars portray financial inclusion as a commercial tool for poverty reduction. ${ }^{45}$ However, it is arguable that despite prejudiced rationales, the necessity of financial inclusion to alleviate low-income and vulnerable groups from poverty is essential to address the risks of financial exclusion. ${ }^{46}$ More so, financial inclusion is depicted as an enabler of achieving the 2030 Sustainability Development Goals (SDG), such as SDG 1 - poverty eradication, SDG 5 - achieving gender equality and economic empowerment of women and SDG 9 - reducing inequality. ${ }^{47}$

According to the UN, financial inclusion is aimed at providing affordable access to a broad range of financial services for vulnerable and low-income groups. ${ }^{48}$ It is also aimed at promoting consumer trust and competition between service providers to curtail the potential of a monopoly and to provide credible financial institutions with transparent and efficient regulations. ${ }^{49}$ Notably, financial inclusion is important for ease and availability of financial products, to manage cash flows, to meet the needs of SME-s, to help with recurring expenditure and to address unexpected emergencies. ${ }^{50}$

\subsection{DIGITAL FINANCIAL SERVICES \& FINTECH INNOVATIONS IN KENYA}

To facilitate financial inclusion and suppress high levels of exclusion, DFS is essential for cost-effective solution offered by banks and mobile money providers through agents without resource for brick and mortar banking infrastructure. ${ }^{51}$ In developing countries, the branch network of banking institutions are absent in rural areas thus perpetuating financial exclusion of low-income

42 Cnaan, R. A., Moodithaya, M. S., Handy, F., 2012, p. 184.

43 Solo, T. M., 2008, pp. 47-66.

44 Fuller, D., Mellor, M., 2008, Banking for the poor: addressing the needs of financially excluded communities in Newcastle upon Tyne, Urban Studies, Vol. 4, No. 7, pp. 1505-1524.

45 Alpana, V., 2007, Promoting financial inclusion: an analysis of the role of banks, Indian Journal of Social Development, Vol. 7, No. 1, pp. 107-126.

46 Cnaan, R. A., Moodithaya, M. S., Handy, F., 2012, p. 184.

47 UNCDF, Financial Inclusion and the SDGs, (https://www.uncdf.org/financial-inclusion-andthe-sdgs, 21. 10. 2020).

48 Klapper, L., 2016, Financial Inclusion Has a Big Role to Play in Reaching the SDGs, (https:// www.cgap.org/blog/financial-inclusion-has-big-role-play-reaching-sdgs, 3. 11. 2020).

49 Ibid.

50 Nageswara R. D., 2018, The Global Digital Financial Services: A Critical Review to Achieve for Digital Economy in Emerging Markets, International Research Journal of Human Resources and Social Sciences, Vol. 5, No. 1, pp. 159-160.

51 Gibson, E., Lupo-Pasini, F., and Buckley R. P., 2015, Regulating Digital Financial Services Agents in Developing Countries to Promote Financial Inclusion, Singapore Journal of Legal Studies, Vol. 1, No. 1, pp. 26-45, 27. 
and vulnerable groups. ${ }^{52}$ It is through DFS that such groups can access financial services which governments utilize to promote financial inclusion. ${ }^{53}$ DFS are financial services provided through digital channels such as mobile phones, e-money and mobile money and delivered through bank led and non-bank led models via the internet and telecommunications providers. ${ }^{54}$ In over 80 countries DFS are used by governments to facilitate financial inclusion for millions of unbanked and underprivileged groups in remote areas. ${ }^{55}$ DFS is a tool that drives financial inclusion through the intersection of technology and financial products to provide easy access to credit facilities through the internet without recourse to traditional brick and mortar banks or financial service providers. ${ }^{56}$ Through DFS, economically disadvantaged groups can easily access affordable and reliable financial services. ${ }^{57}$ It promotes an efficient interface for economic activities between end-users. ${ }^{58}$ Unbanked groups in remote areas can access financial services at lower cost through digital channels. ${ }^{59}$ Basic financial services can be easily accessed through innovations in financial technology. ${ }^{60}$ Through digital finance platforms economically disadvantaged groups can access electronic money and conduct cashless transactions, pay utility bills and receive government payments. ${ }^{61}$ This is already effective in most developed countries where cashless transaction is the preferred means of transacting. ${ }^{62}$

Through digital infrastructure, individuals and businesses can conduct seamless transactions and access financial services using mobile phones and cards over point of sale (POS). ${ }^{63}$ Approximately 2 billion adults in developing countries do not have a bank account and lack access to financial services. ${ }^{64}$ Again, 200 million MSME-s in emerging markets are impeded by the absence

52 Ibid., p. 26.

53 Ibid., p. 26.

54 Gibson, E., Lupo-Pasini, F., and Buckley R. P., 2015, pp. 26-45, 27.

55 Rizzo, M., 2014, Digital Finance: Empowering the Poor via New Technology, online: The World Bank, (https://www.worldbank.org/en/news/feature/2014/04/10/digital-finance-empowering-poor-new-technologies, 20. 10. 2020); Alexandre, C., Eisenhart, L. C., 2013, Mobile Money as an Engine of Financial Inclusion and Lynchpin of Financial Integrity, Washington Journal of Law, Technology and Arts, Vol. 8, No. 1, p. 285; Klein, M., Mayer, C., 2011, Mobile Banking and Financial Inclusion: The Regulatory Lessons, World Bank Policy Research Working Paper No 5664; Veniard, C., 2010, How Agent Banking Changes the Economics of Small Accounts, (delivered at the Global Saving Forum).

56 Loubere, N., 2017, China's Internet Finance Boom and Tyrannies of Inclusion China Perspectives, Vol. 4, No. 112, pp. 9-18, 19.

57 Nageswara, R. D., 2018, The Global Digital Financial Services: A Critical Review to Achieve for Digital Economy in Emerging Markets, Vol. 5, No. 1, International Research Journal of Human Resources and Social Sciences, pp. 159 - 160, 141.

58 Ibid., p. 141.

59 Ibid.

60 Nageswara R. D., 2018, p. 141.

61 Ibid., p. 142.

62 Ibid.

63 Ibid., p. 143.

64 Demirguc-Kunt, A., Klapper, L., Singer, D., Oudheusden, P. van, 2015, The Global Findex Database 2014: Measuring financial inclusion around the world. Policy research working pa- 
of accessible credit to perpetuate their lifespan. ${ }^{65}$ Beyond underprivileged and low-income groups, the middle class in emerging markets are also affected by the problem of financial exclusion. ${ }^{66}$ The absence of financial services stifles and limits the economic growth of financially excluded groups who would otherwise benefit from savings, remittance and insurance products. In the absence of accessible financial service, individuals and businesses resort to risky and expensive options from informal predatory financial systems to avert loss of business opportunities. ${ }^{67}$ DFS is mostly used in developing economies to deliver financial services through innovative digital channels with structured electronic payment platforms, mobile phone and other devices to drive financial inclusion. ${ }^{68}$ DFS provides cost-efficient means to access financial services through electronic payment systems ${ }^{69}$ Studies show that DFS fosters financial inclusion, economic growth and the poverty alleviation. ${ }^{70}$

In Sub-Saharan Africa, through digital channels and the use of bank agents there has been an increase in account ownership by $34 \%$ of people in rural areas. ${ }^{71}$ Over $12 \%$ of adults have a mobile money account. ${ }^{72}$ Even with the solutions provided by DFS, barriers to financial inclusion still limit economically excluded groups from integrating into formal financial systems. ${ }^{73}$ Digital financial channels can be beneficial to curb corrupt practices in government expenditure by reducing unaccounted expenditures through transparency in transactions. ${ }^{74}$

\subsubsection{M-pesa}

In 2007 Kenya launched M-pesa a mobile financial service to transform access to finance for its large population. ${ }^{75} \mathrm{M}$-pesa is a Swahili word that means

per 7255, World Bank, (https://www.worldbank.org/content/dam/Worldbank/Research/GlobalFindex/PDF/N2Unbanked.pdf, 31. 10. 2020).

Ibid.

66 Nageswara, R. D., 2018, p. 149.

67 Abheek, B., Kathuria, R., Malik, N., 2016, The Status of Financial Inclusion, Regulation, and Education in India, ADBI Working Paper 568. Tokyo: Asian Development Bank Institute, (http://www.adb.org/publications/status-financial-inclusion-regulation-andeducation-india/, 9. 11. 2020); Nageswara, R. D., 2018, pp. 159-160, 149.

68 David-West, O., Iheanachor, N., Kelikume, I., 2018, A resource-based view of digital financial services (DFS): An exploratory study of Nigerian providers, Journal of Business Research, Vol. 88, No. 1, pp. 513-526, 513.

69 David-West, O., E-commerce management in emerging markets, in: Lee, I. (ed.), 2016 Encyclopedia of E-commerce Development, Implementation, and Management, (http://dx.doi. org/10.4018/978-1-4666-9787-4, 9. 11. 2020).

70 Hermes, N., Lensink, R., 2013, Financial Development and Economic Growth: Theory and Experiences from Developing Countries, Routledge.

71 David-West, O., Iheanachor, N., and Kelikume, I., 2018, p. 513.

72 Demirguc-Kunt, A., Klapper, L., Singer, D., Oudheusden, P. van, 2015.

73 Nageswara R. D., 2018, pp. 159-160.

74 Ibid., p. 160.

75 Morawczynski. O., 2009, Exploring the Usage and Impact of "Transformational" Mobile Financial Services: The Case of M-PESA in Kenya, Journal of Eastern African Studies, Vol. 3, No. 3, pp. 509-525, 509. 
Mobile-money. ${ }^{76}$ It provides access to several essential financial services and products through mobile phones for consumers to save, withdraw, transfer funds to other users and pay bills like water electricity, health and education. ${ }^{77}$ Over 7 million customers are registered on M-pesa. ${ }^{78}$ It utilizes an agent network with over 10,000 retail outlets managed by agents, who provide consumers with transactional services. ${ }^{79}$ Such services provide low-income and vulnerable groups with opportunities to access the formal economy. ${ }^{80}$ More so, agents are used to provide financial literacy to underserved and underprivileged communities to promote their participation and integration into formal financial systems. ${ }^{81}$

Agents operate independent services in retail outlets, gas stations or postal offices to provide end-users with deposit and withdrawal customer interface on behalf of banks or Mobile Network Operators (MNO) ${ }^{82}$ M-pesa network do not require traditional accounts but function through mobile phones and sim cards, to access digital money ${ }^{83}$ The funds are held in trust and deposited in regulated financial banks. ${ }^{84} \mathrm{M}$-pesa is aimed at promoting sustainable development as it addresses the barrier of remoteness resulting in financial exclusion. ${ }^{85}$ It allows users to exchange cash for electronic currency on their phones and transact with the same ${ }^{86}$ The increase in the use of mobile phones in Africa have transformed information technology such that over $60 \%$ of Africans can access mobile phone coverage and internet access. ${ }^{87}$ Through access to digital channels, within eight months of the inception, over 1.1 million Kenyans had registered to use M-pesa and over $\$ 87$ million had been transferred via this mobile money platform. ${ }^{88}$ In 2009 , more than 8.5 million Kenyans were registered in M-pesa and \$3.7 billion had been transferred over the system. ${ }^{89}$ It has gained high penetration and reach to over 17 million customers including unbanked, low-income and vulnerable groups. ${ }^{90}$

76 Wamalwa, N., 2019, Sustainable Development Goals: The Case of Safaricom Limited, Cyprus, University of Nicosia.

77 Gibson, E., Lupo-Pasini, F., Buckley, R.P., 2015, Regulating Digital Financial Services Agents in Developing Countries to Promote Financial Inclusion, Singapore Journal of Legal Studies, Vol. 1, No. 1, pp. 26-45, 30.

78 Morawczynski. O., 2009.

79 Morawczynski. O., 2009, p. 509.

80 Ibid., p. 510.

81 Gibson, E., Lupo-Pasini, F., Buckley, R. P., 2015, p. 30.

82 Ibid., p. 27.

83 Gibson, E., Lupo-Pasini, F., Buckley R. P., 2015, p. 30.

84 McKay. C., Mazer, R., 2014, 10 Myths about M-PESA: 2014 update, CGAP, (http:/cgap.org/ blog/10-myths-about-m-pesa-2014, 20. 11. 2020).

85 Morawczynski. O., 2009, pp. 509-525, 510.

86 Morawczynski. O., 2009, p. 510.

87 Aker, J.C., 2010. Information from Markets Near and Far: The Impact of Mobile Phones on Agricultural Markets in Niger, American Economic Journal: Applied Economics, Vol. 2, No. 1, pp. 46-59.

88 Mbiti, I., Weil, D.N., (eds.), 2016, Mobile Banking: The Impact of M-Pesa in Kenya, University of Chicago Press, pp. 247-293, 247.

89 Ibid., p. 247.

90 CGAP, 2008, Regulating Transformational Branchless Banking: Mobile Phones and Other Technology to Increase Access to Finance, CGAP Focus Note No 43 Washington, DC, 
Though there is limited empirical evidence on the impact of mobile financial services on poverty reduction, ${ }^{91}$ in Developing countries, there is a propensity for fraud and other financial crimes associated with DFS provided by agents. ${ }^{92}$ Efficient legal framework and regulation is required for effective agent network to create an environment of trust for vulnerable and low-income groups. ${ }^{93}$ It is essential to clarify the allocation of liability to regulate enforcement and consumer protection. ${ }^{94}$ This will reduce the burden of expensive litigation costs and address other issues of contractual and information asymmetry to create consumer trust. ${ }^{95}$

This raises questions on whether it is efficient for the agent to personally bear the liability or for the principal to bear the liability with the end goal of promoting financial inclusion and benefiting end users? ${ }^{96}$ This shows the importance of efficient regulation of DFS to promote financial inclusion and enhance the living conditions of vulnerable groups. ${ }^{97}$ The operations of DFS is associated with cost of compliance and legal action from contractual agreement which requires the agent to account for such costs against the profit margins. ${ }^{98}$

It is notable that burdensome regulations and compliance requirement can hinder the services provided by agents and affect the reach of mobile money services to unbanked groups. ${ }^{99}$ Thus, the need for policy measures that mitigate the risk in DFS and address consumer protection issues to foster financial inclusion through DFS. ${ }^{100}$

\section{INNOVATIONS IN THE PAYMENT SERVICES DIRECTIVE AND THE ALTERNATIVES TO BANKING SERVICES}

\subsection{PAYMENT SERVICES DIRECTIVE}

The first Payment Services Directive (PSD) of 2007 was aimed to create efficient market for payment services in the European Union (EU) with uniform requirements for various forms of electronic payments systems. ${ }^{101}$ This is an

(http:/www.cgap.org/sites/default/files/Focus-Note-Regulating-Transformational-Branchless-Banking-Mobile-Phones-and-Other-Technology to-Increase-Access-to-Finance-Jan-2008. pdf, 11. 11. 2020); Gibson, E., Lupo-Pasini, F., Buckley, R.P., 2015, Regulating Digital Financial Services Agents in Developing Countries to Promote Financial Inclusion, Singapore Journal of Legal Studies, Vol. 1, No. 1, pp. 26-45, 30.

91 Morawczynski, O., 2009, p. 510.

92 Lauer, K., Dias, D., Tarazi, M., 2011, Bank Agents: Risk Management, Mitigation, and Supervision, CGAP Focus Note, No 75, Washington, pp. 4-5.

93 Ibid.

94 Gibson, E., Lupo-Pasini, F., Buckley, R.P., 2015, p. 28.

95 Ibid.

96 Ibid.

97 Ibid.

98 Ibid.

99 Ibid., p. 31.

100 Ibid.

101 Directive 2007/64/EC of the European Parliament and of the Council. The Payment Services Directive [1] (PSD, 2007/64/EC) (Eur-lex.europa.eu., 11. 11. 2020). 
EU Directive administered by the European Commission to regulate payment services and payment service providers throughout the EU and the European Economic Area (EEA). ${ }^{102}$ It is specifically aimed to develop the Eurozone's cross-border payment system known as the Single Euro Payment Area (SEPA) to increase consumer protection and trust. ${ }^{103}$

The Directive is aimed at increasing competition and the EU single market in goods and services through participation in payment industry and to harmonize consumer protection and the rights and obligations for payment services providers and end-users. ${ }^{104}$ In 2015, the second Payment Services Directive (PSD II) was adopted by the European Commission to create transparent and innovative payment systems. ${ }^{105}$ Member states were required to domesticate the directive into their local laws by 2018. ${ }^{106}$ The reformed Payment Services Directive was aimed at improving consumer protection in electronic payment systems to promote the use of innovative digital payment channels. ${ }^{107}$ It introduced third party providers (TPP-s) with unbiased access to banking systems to provide innovative payment solutions to consumers. ${ }^{108}$ This addresses the barrier that impedes TPP-s from providing cost-effective payment solutions on a large scale within the EU. ${ }^{109}$ By inference, the directive utilizes moderate regulation to promote diverse solutions and reduce burdensome compliance requirements. ${ }^{110}$ The Directive also promotes consumer protection and safe transactions to avert fraud. ${ }^{111}$ More so, it fosters easeful connectivity and data access through electronic payment systems via internet banking. ${ }^{112}$ Again, it promotes competition in a non-discriminatory way through inno-

102 Możdżyński, D., 2017, p. 50.

103 Brener, A., Payment Service Directive II and Its Implications, in: Lynn, T., Mooney, J., Rosati, P., Cummins, M. (eds.), 2019, Disrupting Finance. Palgrave Studies in Digital Business \& Enabling Technologies. Palgrave Pivot, Cham. (https://doi.org/10.1007/978-3-030-02330-0_7, 12. 11. 2020) p. 105.

104 Directive on Payment Services (PSD). EU Commission Ec.europa.eu; Donnelly, M. 2016, Payments in the digital market: Evaluating the contribution of Payment Services Directive II. Computer Law \& Security Review, Vol. 32, No. 6, pp. 827-839.

105 Możdżyński, D., 2017, p. 50.

106 Brener, A., 2019, p. 109.

107 EU Commission. European Parliament adopts European Commission proposal to create safer and more innovative European payments.

108 Możdżyński, D., 2017, p. 51.

109 European Commission - Fact Sheet, Payment Services Directive: frequently asked questions, Brussels, 2015.

110 Romānova, I., Spiteri, J., Grima, S., Kudinska, M., 2018, The Payment Services Directive 2 and Competitiveness: The Perspective of European Fintech Companies, European Research Studies Journal, Vol XXI, No. 2, p. 13; Stewart, L.A., 2010, The Impact of Regulation on Innovation in the United States: A Cross-Industry Literature Review, Information Technology \& Innovation Foundation, June.

111 Mersch, Y., 2019, Lending and Payment Systems in Upheaval: the Fintech Challenge. European Central Bank, (https://www.ecb.europa.eu/press/key/date/2019/html/ecb.sp190226 d98d307ad4.en.html, 11. 11. 2020).

112 Możdżyński, D., 2017, p. 51. 
vations in FinTech and the development of digital payment channels within the EU such that traditional financial services as well as non-banking financial institutions can provide financial services to customers. ${ }^{113}$ This promotes innovation within service providers to ensure extensive options and create consumer-oriented solutions. ${ }^{114}$ This also provides several channels for service providers to meet the needs of end-users. The use of innovation, light regulatory burden, promotion of competition and the element of reciprocity within member states which the payment services directive exemplifies is one that policy-drafters in developing economies can learn from to enact policies for DFS. As seen from the case study of M-pesa, with the appropriate level of agent regulation and consumer protection laws the needs of financially excluded groups can be met through non-discriminatory policies that promote innovation and competition.

It is also significant that the directive fosters cost-effective payment solutions to facilitate customer trust through an efficient consumer protection framework against fraud and other financial crimes. ${ }^{115}$ To achieve this, efficient security models would be required. ${ }^{116}$ The directive also adopted secured consumer authentication (SCA) as part of measures against fraud to protect end-users. ${ }^{117}$ This verifies the identity of end-users and their right to make a transaction before same is approved with the primary aim of safeguarding end-users against fraud. ${ }^{118}$ It thus reflects the promotion of consumer trust as an essential objective of the directive. ${ }^{119}$ Furthermore, the directive provides safeguards for individual customers and micro-enterprises within the EU. ${ }^{120}$ Customers are afforded a refund for unauthorized transactions in the absence of fraud on the part of the customer. ${ }^{121}$ It requires member states to provide effective recourse mechanism through transparent and impartial alternative dispute resolution to address issues between consumers and payment services providers within 15 working days of receipt of complaint. ${ }^{122}$ Policy drafters can learn from the solutions imbedded in the payment services directives to address gaps of consumer protection in DFS and boost consumer trust.

113 Romānova, I., Spiteri, J., Grima, S., Kudinska, M., 2018, pp. 5, 9; PSD II, Recital 50 and Art 69.

114 Romānova, I., Spiteri, J., Grima, S., Kudinska, M., 2018, pp. 5, 9.

115 Ibid.

116 Brener, A., 2019.

117 Ibid.

118 Mansfield-Devine, S., 2016. Open Banking: Opportunity and Danger. Computer Fraud \& Security, Vol. 1, No. 10, pp. 8-13; European Commission - Fact Sheet - PSD II: frequently asked questions, 2018, (http://europa.eu/rapid/press-release_MEMO-15-5793, 11. 11. 2020); Supplementing Directive 2015/2366 of the European Parliament and of the Council with regard to RTS for SCA and common and secure open standards of communication, (http:// ec.europa.eu/finance/docs/level-2-measures/psd2-rts-2017-7782_en.pdf).

119 Brener, A., 2019, p. 113.

120 Ibid.; PSD II Art 4 (36).

121 PSD II, Arts 73-74.

122 Ibid., Art. 101, Art. 102. 


\subsection{ALTERNATIVES TO BANKING SERVICES}

The rise of internet finance has changed how financial services are accessed. ${ }^{123}$ More so, the use of light regulation enables DFS to operate with more freedom and innovation as compared to traditional financial institutions. ${ }^{124}$ It thus promotes access to finance and inclusion for excluded groups in remote areas. ${ }^{125}$ In China, financial services can easily be accessed through digital channels. ${ }^{126}$ China's economy is considered one of the largest economies for reducing poverty rates and improving inclusive finance through financial technology. ${ }^{127}$ Through digital financial channels, underserved groups in rural areas can access financial services and contribute to formal economic systems. ${ }^{128}$ China's digital finance industry is driven by innovation and diversity such that remote groups can access a wide range of financial products. ${ }^{129}$ We-chat pay and Alipay are giant digital payments tools which promote financial access to rural groups. ${ }^{130}$ With a broad range of services such as internet payments, internet lending, internet money market funds, internet insurance and investment which continue to experience high growth rate. ${ }^{131}$ Alternatives in banking services are provided through the integration of finance and technology to facilitate access to finance for remote groups through financial services such as online banking, third-party payment, online insurance, crowdfunding, credit scoring platform, blockchain and security, extending loans, selling securities and $\mathrm{p} 2 \mathrm{p}$ lending. ${ }^{132}$ This represents a global movement to enhance access to credit for vulnerable and low-income groups to promote socio-economic development from the grassroot. ${ }^{133}$ Although fraudulent abuses have adversely affected the impact of DFS, same can be addressed through effective regulation to promote consumer confidence. ${ }^{134}$

\section{CAUSES OF FINANCIAL EXCLUSION}

According to the World Bank's Global Financial Inclusion Database over two billion people are financially excluded worldwide. ${ }^{135}$ The issue is evident

123 Loubere, N., 2017, China's Internet Finance Boom and Tyrannies of Inclusion China Perspectives, Vol. 4, No. 112, pp. 9-18, 9.

124 Ibid.

125 Ibid.

126 Ibid.

127 Ibid.

128 Ibid., pp. 9-18, 9-10.

129 Ibid.

130 Ibid.

131 Ibid.

132 Loubere, N., 2017, pp. 9-18, 9-10; China has 6,000 p2p lending platforms for transaction worth 1trillion yuan in 2016.

133 Ibid., pp. 9-18, 10.

134 Ibid.

135 Cnaan, R. A., Moodithaya, M. S., Handy, F., 2012, Financial Inclusion: Lessons from Rural South India, Journal of Social Policy, Vol. 1, No. 41, pp. 183-205, (http://dx.doi.org/10.1017/ S0047279411000377, 3. 11. 2020) p. 188. 
in developing and developed countries as studies conducted by the Federal Deposit Insurance Corporation (FDIC) in 2013 show that $27.7 \%$ of US households are unbanked. ${ }^{136}$ Further studies show that in developing countries, access to financial services through financial institutions is problematic while in developed countries vulnerable and low-income groups are excluded due to difficulty in understanding financial tools and the expensive cost of accessing financial services. ${ }^{137}$ Financial exclusion can occur due to financial illiteracy or inaccessibility to financial services. ${ }^{138}$ Barriers that distance people from accessing financial services can result in financial exclusion. ${ }^{139}$ They include physical exclusion caused by the absence of financial services in remote areas, admission exclusion caused by risk assessment which result in exclusion, price exclusion caused by expensive cost of access and self-exclusion caused by previous experience or illiteracy. ${ }^{140}$ Consequently, this results in recourse to informal financial services which are risky and more expensive as short-term loans are overpriced for unbanked groups. ${ }^{141}$ A group might be unbanked due to discrimination on social, religious or ethnic grounds. ${ }^{142}$ Again, information and contractual asymmetry prevents financial inclusion. ${ }^{143}$ More so, the price of financial services may be expensive for households and enterprises to access and at the same time not commercially viable for financial institutions. ${ }^{144}$ The high cost of financial services may be exclusive to some groups thus depriving other groups from accessing such services. ${ }^{145}$ Thus, financial exclusion for different groups can be categorized into "ineligibility, financial illiteracy and non-availability". ${ }^{146}$ The deregulation of financial services in developed markets and the absence of banking policies to integrate unbanked groups in developing markets may result in financial exclusion. ${ }^{147}$

136 Federal Deposit Insurance Corporation, 2013, FDIC national survey of unbanked and underbanked households, (https://fdic.gov/household survey/2013report.pdf, 27. 10. 2020).

137 World Bank, 2005, Mexico - Broadening Access to Financial Services among the Urban Population: Mexico City's Unbanked, Report No. 32418 Washington.

138 Cnaan, R. A., Moodithaya, M. S., Handy, F., 2012, pp. 184-185.

139 Ibid.

140 Leyshon, A., Signoretta, P., French, S., 2006, The Changing Geography of British Bank and Building Society Branch Networks, 1995-2003, (http://www.nottingham.ac.uk/geography/general/news-events/, 10. 11. 2020) p. 161.

141 Cnaan, R. A., Moodithaya, M. S., Handy, F., 2012, pp. 183-185; Amaeshi, K. M. 2006, Financial exclusion, financial institutions and corporate social responsibility: a developing country perspective, Working Paper, Social Science Research Network (SSRN), Rochester, NY.

142 Cnaan, R. A., Moodithaya, M. S., Handy, F., 2012.

143 Ibid.

144 Jong-Hee, K., 2016, p. 499; World Bank Group, 2008, Finance for All? Policies and Pitfalls in Expanding Access, Policy Research Report, 2007033387, Washington, (https://openknowledge.worldbank.org/bitstream/handle/10986/6905/417920PAPER0Fi18082137291301PUBL IC1.pdf?sequence=1\&isAllowed $=y, 28.10 .2020$ ).

145 Jong-Hee, K., 2016, p. 499.

146 Ibid.

147 Cnaan, R. A., Moodithaya, M. S., \& Handy, F., 2012, (http://repository.upenn.edu/spp_papers/164), p. 186. 
In the absence of regulation, banks can prioritize affluential clients to increase their profits and forgo the needs of underserved groups. ${ }^{148}$ Proper assessment and knowledge of groups that are prone to exclusion aids the process of achieving financial inclusion. ${ }^{149}$ Women and those in semi-skilled jobs are mostly without access to financial services while men in middle to high-income groups tend to enjoy more access to financial services. ${ }^{150}$ In Ethiopia, only $22 \%$ of adults possess a formal financial account with over 70 percent of the population resident in rural areas without access to bank branches or automated teller machine (ATM). Citation missing in India, the distance between financial services and the rural groups requires a day's journey to access deposit or withdrawal services. ${ }^{151}$ Over $\$ 2$ billion is foregone annually due to the extensive travel time to access financial services. ${ }^{152}$ Globally, $23 \%$ of adults referred to unaffordability of annual fees and transaction cost as reasons for not having accounts in financial institutions. ${ }^{153}$ This is evidence of inadequate regulation, lack of competition and innovation to provide affordable services for unbanked groups. ${ }^{154}$ Exclusion is reflected in burdensome conditions and expensive costs that hamper access or self-exclusion as a result of past experiences or a lack of information on the benefits of formal financial system. ${ }^{155}$ Financial exclusion can affect access to opportunities for economic advancement due to high cost of accessing credit at the informal sector. ${ }^{156}$ Thus, the need for reforms in financial systems to foster access and economic development, ${ }^{157}$ more so, the need for policy measures to facilitate financial inclusion and financial stability. ${ }^{158}$

\subsection{ISSUES OF CONSUMER PROTECTION IN DFS}

Targeted consumers are those that are novel to financial products and lack understanding of their own needs to fully benefit from financial services. ${ }^{159}$ This keeps them excluded due to ill-financial literacy and a lack of awareness

148 Ibid.

149 Ibid.

150 Heimann, M., Mylenko, N., 2011, Access to Financial Services and the Financial Inclusion Agenda around the World: A Cross-Country Analysis with a New Data Set, Policy Research Working Paper Series 5537, Washington, DC: The World Bank, (http://wwwwds.worldbank. org/servlet/WDSContentServer/WDSP/IB/2011/01/18/000158349_20110118141442/Rendered/PDF/WPS5537.pdf, 11. 11. 2020).

151 Ibid.

152 Nageswara R. D., 2018, pp. 159-160, 151-152.

153 Ibid., pp. 159-160, 154.

154 Ibid.

155 Jong-Hee, K., 2016.

156 Ibid.

157 Ibid.

158 Ibid., p. 500; Morgan, P., Pontines, V., 2014, Financial Stability and Financial Inclusion, ADB Working paper, 488, Manila, Philippines.

159 Gummi, M., Finke, L., Pizatella-Haswell, R., Manasa, Y. T., Consumer Protection in Financial Technology: Risks Unbanked and Underbanked Consumers face in Digital Credit and the Technological and Regulatory Approaches to Mitigate Risk, (http://www.digitalcreditobser- 
on financial products and digital payment solutions. ${ }^{160}$ In some cases, a lack of transparency from financial service providers results in information asymmetry and leads consumers to make misinformed decision. ${ }^{161}$ This then results in withdrawal from formal financial systems. ${ }^{162}$ Again, predatory lenders use over-indebtedness to trap low-literacy and low-income groups with bad credit records. ${ }^{163}$ Due to the limited options for vulnerable groups, they are susceptible to burdensome fees and aggressive repayment terms ${ }^{164}$ thus, increasing their indebtedness and inability to meet repayment terms. ${ }^{165}$

More so, the presence of inefficient regulation for digital financial service providers results in the exploitation of consumers through excessive charges to increase profit at the expense of consumers. ${ }^{166}$ There is also a disparity between consumer needs and financial products owing to the absence of adequate needs assessment to measure the appropriate needs and priorities of consumers. ${ }^{167}$ In the absence of efficient legal framework and accessible services in remote areas, consumers resort to predatory loan providers and incur high costs with stringent loan terms. ${ }^{168}$ Consumers are also vulnerable to fraudulent attacks and data thefts from hackers due to information and privacy breaches by service providers. ${ }^{169}$ This can be harmful and disadvantageous for consumers. ${ }^{170}$ Under contractual agreements, the liability of fraudulent account activities are imposed solely on consumers owing to the absence of effective processes to address fraud as fraud redressal system are rather absent in emerging markets. ${ }^{171}$ More so, consumers lack adequate recourse mechanism to address fraud due to information asymmetry and the unique risk it presents. ${ }^{172}$

\subsection{POLICY MEASURES FOR CONSUMER PROTECTION}

To provide effective measures for consumer protection there is need to create a balance between effective supervision and compliance of market players. ${ }^{173}$ In the absence of efficient consumer protection, financial exclusion will be per-

vatory.org/uploads/8/2/2/7/82274768/consumer_protection_in_financial_technology_gspp. pdf, 11. 11. 2020) p. 19.

160 Gummi, M., Finke, L., Pizatella-Haswell, R., Manasa, Y. T., p. 19.

161 Ibid.

162 Ibid., pp. 21-23.

163 Ibid.

164 Ibid.

165 Ibid.

166 Ibid., p. 14.

167 Ibid., p. 27.

168 Ibid., pp. 27-28.

169 Ibid., p. 30.

170 Ibid.

171 Ibid., p. 37.

172 Ibid., p. 38.

173 Alliance for Financial Inclusion, 2010, Consumer Protection Leveling the Playing Field in Financial Inclusion, Policy Note, Bangkok, Thailand, (https://www.afi-global.org/sites/default/ files/publications/afi_policynote_consumerprotection_en128.pdf) p. 1. 
petuated and the benefits of inclusion will be ineffective. ${ }^{174}$ To address the gaps of information imbalance, there is need for policies that mandate sufficient disclosure of information for consumers such that it fosters financial literacy for consumers to fully benefit from financial services. ${ }^{175}$

To improve financial literacy, consumers should be educated to fully understand the benefits of financial services. Also, financial institutions should be mandated to provide such services to facilitate consumer protection. ${ }^{176}$ Governments should likewise enforce financial literacy through introducing financial education for consumers. ${ }^{177}$ Through appropriate regulation, information asymmetry can be curtailed such that contractual agreements are transparent, to enable consumers understand their rights and obligations in relation to financial services. ${ }^{178}$ Consumers should be offered protection that reflects their concerns from needs based assessments as opposed to the concerns of the product. ${ }^{179}$ More so, regulatory measures should be tailored to address the concerns of consumers rather than that of service providers. ${ }^{180}$ This will ensure fair conditions for both consumers and service providers. ${ }^{181}$ Through transparent and fair conditions, consumers can be protected from predatory practices that are misleading and make informed decisions. ${ }^{182}$

Also, the use of effective redress mechanism is needful to clarify the allocation of risk and liability to provide adequate protection to consumers. ${ }^{183}$ This ascertains the right of consumers to recourse and enhances consumer trust and confidence in DFS. More so, redress should be provided in a transparent and unprejudiced manner by an independent party or agency. ${ }^{184}$ The government can mandate financial education and literacy to address gaps of information asymmetry. ${ }^{185}$

Again, through credit counselling services such as financial management, debt management can be provided to support over-indebted consumers who face difficulty in meeting their financial obligations. ${ }^{186}$ More so, maintaining privacy of consumer personal financial information is important to protect consumers against fraudulent and improper use of their financial information. ${ }^{187}$

Although this is not often considered in consumer protection framework, ${ }^{188}$ it is notable that appropriate and efficient consumer protection laws can facili-

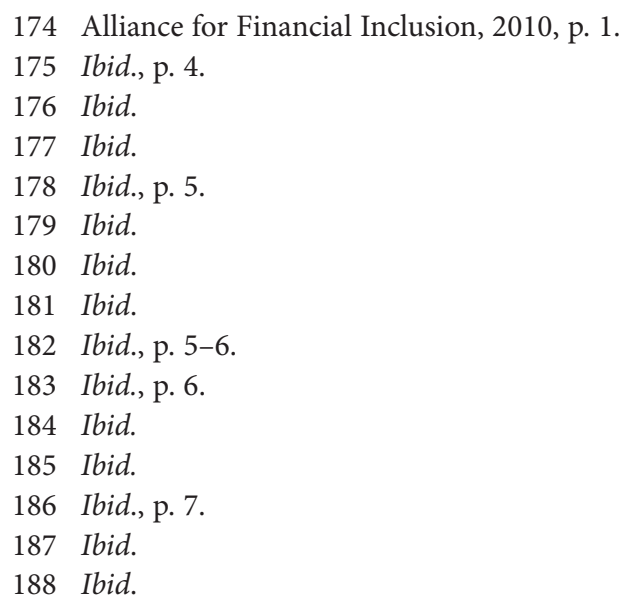


tate financial inclusion. ${ }^{189}$ It thus serves as a tool to address financial exclusion within vulnerable and underserved groups. The importance of an adequate consumer protection framework in DFS is critical to promote financial inclusion amongst underserved and vulnerable groups. In the absence of adequate consumer protection framework, the trust and confidence of end-users will decline and thus result in financial exclusion.

\section{CONCLUSION}

In conclusion, this paper has analyzed financial inclusion and its objective centering on promoting easeful and safe access to financial services for consumers such that vulnerable and low-income groups can be integrated into formal financial systems. It also looked at the objectives of financial inclusion and showed the link between the SDG and the achievement of financial inclusion as accessing formal financial services can facilitate the poverty reduction and address the issues of gender inequality. This paper also extensively examined DFS and the innovation in payment systems referring to the 2015 Payment Services Directive. It has shown that DFS is a tool to promote financial inclusion such that through bank led and non-bank led models via internet channels remote groups can access financial services and foster their economic development. More so, it exemplifies M-pesa as a DFS that provides for easeful access of financial services and products such as savings, withdrawal and payment of bills.

However, this paper shows that DFS are not without consumer protection issues owing to ineffective regulation which the Payment services directive addresses to promote consumer trust and confidence. This paper investigated the aims of the updated Payment Services Directive which is focused on driving consumer protection, competition and innovative solution-oriented services to enhance inclusive finance processes within the EU. It further showed the alternatives to banking services such as online banking, internet insurance, internet investment, crowdfunding and $\mathrm{p} 2 \mathrm{p}$ lending, all of which are transformative methods for accessing financial services. However, this paper adduces to the gaps of achieving financial inclusion through DFS evinced in weak consumer protection framework such as information asymmetry, financial illiteracy, high cost of accessing finance, inaccessibility to financial services and discrimination.

It also assessed the issues of consumer protection such as breach of consumer privacy, absence of needs assessment to address the concerns of consumers, absence of fraud redressal systems and predatory practices of service providers. Finally, this paper has proffered policy consideration to address consumer protection issues in DFS through effective supervision, sufficient disclosure measures, adequate financial literacy and recourse mechanism. 


\section{BIBLIOGRAPHY}

1. Amaeshi, K. M., 2006, Financial Exclusion, Financial Institutions and Corporate Social Responsibility: A Developing Country Perspective, Working Paper, Social Science Research Network (SSRN), Rochester, NY.

2. Aker, J. C., 2010, Information from Markets Near and Far: The Impact of Mobile Phones on Agricultural Markets in Niger, American Economic Journal: Applied Economics, Vol. 2, No. 1.

3. Alexandre, C., Eisenhart, L. C., 2013, Mobile Money as an Engine of Financial Inclusion and Lynchpin of Financial Integrity, Washington Journal of Law, Technology and Arts, Vol. 8, No. 1.

4. Alpana, V., 2007, Promoting Financial Inclusion: An Analysis of the Role of Banks, Indian Journal of Social Development, Vol. 7, No. 1.

5. CGAP, 2008, Regulating Transformational Branchless Banking: Mobile Phones and Other Technology to Increase Access to Finance, CGAP Focus Note No 43 Washington, DC, (http:/www.cgap.org/sites/default/files/Focus-Note-Regulating-Transformational-Branchless-Banking-Mobile-Phones-and-Other-Technology to-IncreaseAccess-to-Finance-Jan-2008.pdf, 11. 11. 2020).

6. David-West, O., E-Commerce Management in Emerging Markets, in: Lee, I. (ed.), 2016, Encyclopedia of E-Commerce Development, Implementation, and Management, (http://dx.doi.org/10.4018/978-1-4666-9787-4, 9. 11. 2020).

7. David-West, O., Iheanachor, N., and Kelikume, I., 2018, A Resource-Based View of Digital Financial Services (DFS): An Exploratory Study of Nigerian Providers, Journal of Business Research, Vol. 88, No. 1.

8. Donnelly, M., 2016, Payments in the Digital Market: Evaluating the Contribution of Payment Services Directive II, Computer Law \& Security Review, Vol. 32, No. 6.

9. European Commission - Fact Sheet, Payment Services Directive: Frequently Asked Questions, Brussels, 2015.

10. Fuller, D., Mellor, M., 2008, Banking for the Poor: Addressing the Needs of Financially Excluded Communities in Newcastle upon Tyne, Urban Studies, Vol. 4, No. 7.

11. Gibson, E., Lupo-Pasini, F., Buckley, R. P., 2015, Regulating Digital Financial Services Agents in Developing Countries to Promote Financial Inclusion, Singapore Journal of Legal Studies, Vol. 1, No. 1.

12. Hermes, N., Lensink, R., 2013, Financial Development and Economic Growth: Theory and Experiences from Developing Countries, Routledge.

13. Jong-Hee, K., 2016, A Study on the Effect of Financial Inclusion on the Relationship Between Income Inequality and Economic Growth, Emerging Markets Finance and Trade, Vol. 2, No. 52.

14. Klein, M., Mayer, C., 2011, Mobile Banking and Financial Inclusion: The Regulatory Lessons, World Bank Policy Research Working Paper No 5664.

15. Lauer, K., Dias, D., Tarazi, M., 2011, Bank Agents: Risk Management, Mitigation, and Supervision, CGAP Focus Note No 75, Washington.

16. Leyshon, A., Signoretta, P., French, S., 2006, The Changing Geography of British Bank and Building Society Branch Networks, 1995-2003, (http://www.nottingham.ac.uk/ geography/general/news-events/, 10. 11. 2020).

17. Loubere, N., 2017, China's Internet Finance Boom and Tyrannies of Inclusion, China Perspectives, Vol. 4, No. 112. 
18. Mbiti, I., Weil, D. N., 2016, Mobile Banking: The Impact of M-Pesa in Kenya, (eds.), University of Chicago Press.

19. McKay, C., Mazer, R., 2014, 10 Myths about M-PESA: 2014 update, CGAP, (http:/ cgap.org/blog/10-myths-about-m-pesa-2014, 20. 11. 2020).

20. Morawczynski, O., 2009, Exploring the Usage and Impact of "Transformational" Mobile Financial Services: The Case of M-PESA in Kenya, Journal of Eastern African Studies, Vol. 3, No. 3.

21. Nageswara, R. D., 2018, The Global Digital Financial Services: A Critical Review to Achieve for Digital Economy in Emerging Markets, International Research Journal of Human Resources and Social Sciences, Vol. 5, No. 1.

22. Romānova, I., Spiteri, J., Grima, S., Kudinska, M., 2018, The Payment Services Directive 2 and Competitiveness: The Perspective of European Fintech Companies, European Research Studies Journal, Vol. XXI, No. 2.

23. Solo, T. M., 2008, Financial Exclusion in Latin America - or the Social Costs of not Banking the Urban Poor, Environment and Urbanization, Vol. 20, No. 1.

24. Stewart, L. A., 2010, The Impact of Regulation on Innovation in the United States: A Cross-Industry Literature Review, Information Technology \& Innovation Foundation, June.

25. Veniard, C., 2010, How Agent Banking Changes the Economics of Small Accounts, (delivered at the Global Saving Forum).

26. Wamalwa, N., 2019, Sustainable Development Goals: The Case of Safaricom Limited, Cyprus, University of Nicosia.

27. World Bank, 2005, Mexico - Broadening Access to Financial Services among the Urban Population: Mexico City's Unbanked, Report No. 32418 Washington.

\section{LEGISLATIVE SOURCES}

1. Directive 2007/64/EC of the European Parliament and of the Council. The Payment Services Directive [1] (PSD, 2007/64/EC) (Eur-lex.europa.eu., 11. 11. 2020).

2. Directive on Payment Services (PSD). EU Commission Ec.europa.eu.

3. Payment services (PSD 2) - Directive (EU) 2015/2366, (https://ec.europa.eu/info/ law/payment-services-psd-2-directive-eu-2015-2366_en, 5. 11. 2020).

\section{INTERNET SOURCES}

1. Abheek, B., Kathuria, R., Malik, N., 2016, The Status of Financial Inclusion, Regulation, and Education in India, ADBI Working Paper 568. Tokyo: Asian Development Bank Institute, (http://www.adb.org/publications/status-financial-inclusion-regulation-andeducation-india/, 9. 11. 2020).

2. Alliance for Financial Inclusion, 2010, Consumer Protection Leveling the playing field in financial inclusion, Policy Note, Bangkok, Thailand, (https://www.afi-global. $\mathrm{org} /$ sites/default/files/publications/afi_policynote_consumerprotection_en128.pdf).

3. Annan, K., 2003, General assembly greenlights programme for the international year of microcredit 2005, United Nations press release, (http://www.uncdf.org/english/ microfinance/pubs/newsletter/pages/dec_2003/spotlight.php, 9. 11. 2020).

4. Brener, A., Payment Service Directive II and Its Implications, in: Lynn, T., Mooney, J., Rosati, P., Cummins, M. (eds.), Disrupting Finance. Palgrave Studies in Digi- 
tal Business \& Enabling Technologies. 2019, Palgrave Pivot, Cham. (https://doi. org/10.1007/978-3-030-02330-0_7, 12. 11. 2020).

5. Cnaan, R. A., Moodithaya, M. S., Handy, F., 2012, Financial Inclusion: Lessons from Rural South India, Journal of Social Policy, 41(1). doi: http://dx.doi.org/10.1017/ S0047279411000377, http://repository.upenn.edu/spp_papers/164.

6. Demirguc-Kunt, A., Klapper, L., Singer, D., Oudheusden, P. van, 2015, The Global Findex Database 2014: Measuring financial inclusion around the world. Policy research working paper 7255, World Bank, (https://www.worldbank.org/content/dam/ Worldbank/Research/GlobalFindex/PDF/N2Unbanked.pdf, 31. 10. 2020).

7. European Commission-Fact Sheet-PSD II: frequently asked questions, 2018, (http://europa.eu/rapid/press-release_MEMO-15-5793, 11. 11. 2020).

8. Federal Deposit Insurance Corporation, 2013, FDIC National Survey of Unbanked and Underbanked Households, (https://fdic.gov/household survey/2013report.pdf, 27. 10. 2020).

9. Gummi, M., Finke, L., Pizatella-Haswell, R., Manasa, Y.T., Consumer Protection in Financial Technology: Risks Unbanked and Underbanked Consumers Face in Digital Credit and the Technological and Regulatory Approaches to Mitigate Risk, (http://www.digitalcreditobservatory.org/uploads/8/2/2/7/82274768/consumer_protection_in_financial_technology_gspp.pdf, 11. 11.2020).

10. Heimann, M., Mylenko, N., 2011, Access to Financial Services and the Financial Inclusion Agenda around the World: A Cross-Country Analysis with a New Data Set, Policy Research, Working Paper Series 5537, Washington, DC: The World Bank, (http://wwwwds.worldbank.org/servlet/WDSContentServer/WDSP/IB/2011/01/18/ 000158349_20110118141442/Rendered/PDF/WPS5537.pdf, 11. 11. 2020).

11. https://www.afford-uk.org/ (5. 11. 2020); https://www.afford-uk.org/current-funded-programmes/ (7. 11. 2020).

12. https://www.afford-uk.org/abc-benin-accelerator-programme/ (6. 11. 2020).

13. Klapper, L., 2016, Financial Inclusion Has a Big Role to Play in Reaching the SDGs, (https://www.cgap.org/blog/financial-inclusion-has-big-role-play-reaching-sdgs, 3. 11. 2020).

14. Leeladhar, V., 2005, Taking banking services to the common man - financial inclusion, Mumbai, Reserve Bank of India Bulletin,(https://www.bis.org/review/r051214e.pdf, 3. 11. 2020).

15. Mansfield-Devine, S., 2016, Open banking: Opportunity and danger, Computer Fraud \& Security, Vol. 1, No. 10.

16. Mersch, Y., 2019, Lending and Payment Systems in Upheaval: The Fintech Challenge. European Central Bank, (https://www.ecb.europa.eu/press/key/date/2019/html/ecb. sp190226 d98d307ad4.en.html, 11. 11. 2020).

17. Mitton, L., 2008, Financial Inclusion in the UK: Review of Policy and Practice, (https:// www.jrf.org.uk/report/financial-inclusion-uk-review-policy-and-practice, 27. 10. 2020).

18. Morgan, P., Pontines, V., 2014, Financial Stability and Financial Inclusion, ADB Working paper, 488, Manila, Philippines.

19. Payment services (PSD 2) - Directive (EU) 2015/2366, (https://ec.europa.eu/info/ law/payment-services-psd-2-directive-eu-2015-2366_en, 5. 11. 2020). 
20. Pazarbasioglu, C. et al., 2020, Digital Financial Services, World Bank Group, (http:// pubdocs.worldbank.org/en/230281588169110691/Digital-Financial-Services.pdf, 3. 11. 2020).

21. Rizzo, M., 2014, Digital Finance: Empowering the Poor via New Technology, online: The World Bank, (https://www.worldbank.org/en/news/feature/2014/04/10/digital-finance-empowering-poor-new-technologies, 20. 10. 2020).

22. Shah-Davis, S., Research Methods - Comparative Methodology, (https://uweascllmsupport.wordpress.com/2017/11/15/research-methods-comparative-methodology/, 31. 10. 2020).

23. Stijns, J-P., 2017, Digital Financial Inclusion in sub-Saharan Africa (European Investment Bank) Round Table Proceedings, (https://www.eib.org/attachments/ general/events/africa_day_2017_roundtable_proceedings.pdf?cid=sn_twitter_Report-book_2017-10-18-01_en_na_Region-Africa_InternationalDevelopment-outsideEU, 6. 11. 2020).

24. The World Bank, 2018, Financial Inclusion: Financial Inclusion is a Key Enabler to Reducing Poverty and Boosting Prosperity, (https://www.worldbank.org/en/topic/financialinclusion/overview, 9. 11. 2020).

25. UNCDF, Financial Inclusion and the SDGs, (https://www.uncdf.org/financial-inclusion-and-the-sdgs, 21. 10. 2020).

26. World Bank Group, Credit Infrastructure, (https://www.worldbank.org/en/topic/ creditinfrastructure, 5. 11. 2020).

27. World Bank Group, 2008, Finance for All? Policies and Pitfalls in Expanding Access, Policy Research Report, 2007033387, Washington, (https://openknowledge.worldbank.org/bitstream/handle/10986/6905/417920PAPER0Fi18082137291301PUBLIC1.pdf? sequence=1\&isAllowed=y, 28. 10. 2020).

28. World Bank, 2014, Financial Inclusion, Global Financial Development Report (2014), (https://openknowledge.worldbank.org/bitstream/handle/10986/16238/978082 1399859.pdf? sequence $=4$ \&isAllowed $=y, 8$. 11. 2020).

29. WSBI., 2016, Close to 40 Million EU Citizens Outside Banking Mainstream, (https:// www.wsbi-esbg.org/press/latest-news/Pages/Close-to-40-million-EU-citizens-outside-banking-mainstream.aspx, 29. 10. 2020). 


\title{
FINANSIJSKA UKLJUČENOST KROZ INOVACIJE - POBOLJŠANJE ZAŠTITE POTROŠAČA U DIGITALNIM FINANSIJSKIM USLUGAMA
}

\author{
Esther Angonemi Ebimoghan
}

\begin{abstract}
REZIME
Svrha ovog rada bila je da pokaže kako digitalne finansijske usluge mogu pokrenuti finansijsku inkluziju koja takođe pokreće ekonomski razvoj. Rad je zasnovan na hipotezi da će nedostatak zaštite potrošača produžiti finansijsku isključenost. Kroz uporedno istraživanje sa funkcionalnim pristupom, ovaj rad je proučio kako adekvatna i lagana regulativa olakšava inovacije i konkurenciju digitalnim kanalima kako bi povećala finansijsku uključenost ranjivih i nedovoljno zaštićenih grupa. U reformama evropskih direktiva o platnim uslugama (PSD), istraživački centri usmereni su na povećanje zaštite potrošača i poverenja u upotrebu inovativnih rešenja za digitalno plaćanje. Rad prikazuje nova dostignuća u direktivi, poput uvođenja nezavisnih dobavljača (TPP) i sigurne autentifikacije potrošača (SCA) radi promocije konkurencije kroz inovativna rešenja za plaćanje i zaštitu krajnjih korisnika od prevara. Dokument je takođe ispitao digitalne finansijske usluge (DFS) u Podsaharskoj Africi, koristeći M-pesa kao studiju slučaja. Dalje, ovaj rad je ocenio uzroke finansijske isključenosti i pitanja zaštite potrošača. Glavni nalazi ove studije pokazuju da je finansijska isključenost globalno pitanje kako u razvijenim ekonomijama tako i u ekonomijama u razvoju, ali sa različitim stepenom izazova kao što su nedostatak pristupa finansijskim uslugama, skupi troškovi pristupa i finansijska nepismenost. Rad dalje pokazuje da će, bez odgovarajuće regulative i okvira za zaštitu potrošača za postizanje transparentnosti i odgovornosti putem efikasnog mehanizma regresa, koristi od finansijske inkluzije biti neefikasne i poverenje potrošača će se izgubiti. Stoga, da bi se poboljšala finansijska inkluzija, potrebni su odgovarajuća politička akcija i odgovarajući okvir za zaštitu potrošača.
\end{abstract}

Ključne reči: finansijska inkluzija, M-pesa, Podsaharska Afrika, Evropska unija, Direktiva o platnim uslugama, zaštita potrošača, digitalne finansijske usluge, mobilni novac, Fintech. 